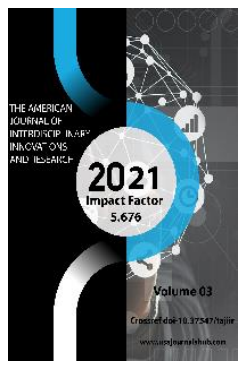

Copyright: Original content from this work may be used under the terms of the creative commons attributes 4.0 licence.

\section{Mathematical Modeling Of Moisture Properties Of Terry Tissue}

Qosimov Axtam Akramovich

Senior Lecturer, Department Of "Metrology, Standardization And Quality Management", Namangan Institute Of Engineering And Technology, Namangan, Uzbekistan

Abdullayev Ulug'bek To'lanbayevich

Candidate Of Technical Sciences, Associate Professor, Vice-Rector For Youth Affairs Of

Tashkent Institute Of Textile And Light Industry, Tashkent, Uzbekistan

\author{
Abdulazizov Shokirjon Abdurashid O'g'li \\ Master Student, Course Of Study “Metrology Standardization And Quality Management \\ Training", Namangan Institute Of Engineering Technology, Namangan, Uzbekistan \\ Hasanboyev Abdurasul Hasanboy O'g'li \\ Bachelor Student, Course Of Study “Metrology Standardization And Quality Management \\ Training”, Namangan Institute Of Engineering Technology, Namangan, Uzbekistan
}

\title{
ABSTRACT
}

This study, designed to design and predict the water-related properties of pili tissue, mainly analyzed the linear density, pili height, and density of pili properties using a mathematical model using a fullfactor experimental method. The article developed a mathematical model of the water absorption and construction properties of piliy textiles and correlated them with the results of practical experiments.

\section{KEYWORDS}

Terry, water distribution radius, water permeability, pili density, pili height, mathematical model.

\section{INTRODUCTION}

Towels are the most commonly used textile product when using terry woven fabrics with water. Users prefer ready-made gowns, towels to be comfortable and fresh, made of light and 
soft construction, to absorb water and sweat accumulated in the body, to dry quickly, to be hygienic and natural. Therefore, convenience for textiles is also an important need for terry fabrics in relation to water [1-4]. The hygroscopic properties of towel products are characterized by their ability to absorb and absorb moisture. We took 18 different samples of woollen fabrics and measured them as the desired parameter by measuring the number of pili strands, the number of loops, the length, thickness and surface density of the $1 \mathrm{~cm}$ loop thread [5-9]. Using the obtained unwanted parameters, we constructed a mathematical model to predict the properties of the High
Surface Moisture Time and the High Surface Moisture Absorption Level Predictability. Table 1 shows a mathematical model of the high surface wetting time of woollen fabrics and provides a model calculation.

$X_{1}$ - Linear density of feather yarn, Ne.

$\mathrm{X}_{2}$ - Number of pili rings in $1 \mathrm{~cm}^{2}$.

$\mathrm{X}_{3}$ - Length of pili strip in $1 \mathrm{~cm}^{2},(\mathrm{~cm})$.

$\mathrm{X}_{4}$-Thickness, (mm).

$\mathrm{X}_{5}$ - Surface density, $\left(\mathrm{g} / 10 \mathrm{~cm}^{2}\right)$.

$Y_{1}$ - High surface wetting time, (s).

$\mathrm{Y}_{2^{-}}$High surface moisture absorption treatment, (\% S).

Table 1. Mathematical model matrix of high surface wetting time and level.

\begin{tabular}{|c|c|c|c|c|c|c|c|}
\hline $\begin{array}{l}\stackrel{\mathbb{N}}{\Xi} \\
\stackrel{\Xi}{\mathbb{E}} \\
\frac{N}{Z}\end{array}$ & 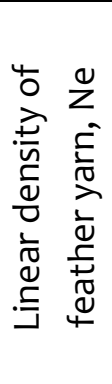 & 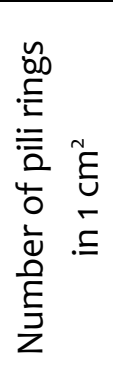 & 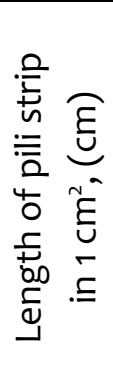 & 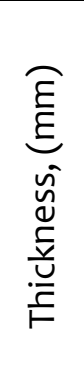 & 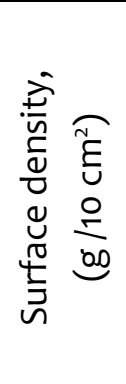 & 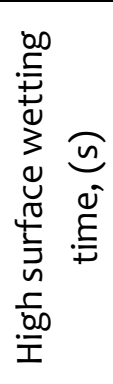 & 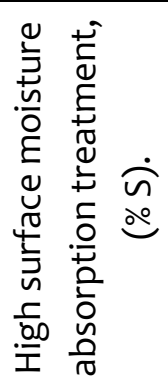 \\
\hline & $X_{1}$ & $\mathrm{X}_{2}$ & $x_{3}$ & $X_{4}$ & $X_{5}$ & $Y_{1}$ & $\mathrm{Y}_{2}$ \\
\hline 1 & $27 / 1$ & 48 & 51,4 & 3,92 & 4,97 & 6,46 & 49,80 \\
\hline 2 & $27 / 1$ & 48 & 50,4 & 4,78 & 4,99 & 6,78 & 48,58 \\
\hline 3 & $27 / 1$ & 48 & 49,0 & 4,25 & 5,07 & 5,68 & 48,65 \\
\hline 4 & $27 / 1$ & 42 & 49,1 & 3,04 & 3,63 & 16,29 & 24,12 \\
\hline 5 & $27 / 1$ & 42 & 48,3 & 3,04 & 3,66 & 17,26 & 23,98 \\
\hline 6 & $27 / 1$ & 42 & 48,7 & 3,02 & 3,69 & 16,89 & 24,15 \\
\hline 7 & $36 / 2$ & 48 & 79,7 & 3,03 & 3,69 & 1,31 & 19,93 \\
\hline 8 & $36 / 2$ & 48 & 81,6 & 3,07 & 3,68 & 2,35 & 19,26 \\
\hline 9 & $27 / 1$ & 72 & 79,9 & 2,81 & 3,65 & 1,98 & 20,21 \\
\hline 10 & $27 / 1$ & 72 & 80,6 & 3,08 & 3,68 & 23,21 & 31,95 \\
\hline 11 & $27 / 1$ & 72 & 80,6 & 3,35 & 3,76 & 22,90 & 30,25 \\
\hline 12 & $27 / 1$ & 64 & 58,2 & 3,40 & 3,73 & 22,96 & 32,52 \\
\hline 13 & $27 / 1$ & 64 & 58,9 & 3,44 & 4,70 & 5,34 & 24,83 \\
\hline 14 & $27 / 1$ & 64 & 58,2 & 3,30 & 4,64 & 6,15 & 24,56 \\
\hline 15 & $36 / 2$ & 56 & 46,5 & 3,30 & 4,67 & 5,89 & 25,01 \\
\hline
\end{tabular}


The American Journal of Interdisciplinary Innovations and Research (ISSN-2642-7478)

Published: May 31, 2021 | Pages: 94-99

Doi: https://doi.org/10.37547/tajiir/Volumeo3Issue05-17

\begin{tabular}{|l|l|l|l|l|l|l|l|}
\hline 16 & $36 / 2$ & 56 & 47,6 & 3,41 & 3,98 & 71,51 & 7,55 \\
\hline 17 & $36 / 2$ & 56 & 45,9 & 3,16 & 4,00 & 70,27 & 7,85 \\
\hline 18 & $36 / 2$ & 56 & 45,9 & 3,16 & 3,98 & 70,59 & 7,26 \\
\hline
\end{tabular}

$\mathrm{Y}_{1}$ - We construct the model using regression analysis to calculate the high surface wetting time (s). This model allows you to calculate the absorption time of a drop of water-based on 5 input factors and has the following appearance.

$\mathrm{Y}_{1}$ - High surface wetting time, $(\mathrm{s})$.

$Y_{1}=83,12+0,58 * X_{1}+1,47 * X_{2}-1,5 * X_{3}+26,05 * X_{4}-$ $40,49 * X_{5}$

Y2- High surface moisture absorption treatment, (\% S).

$\mathrm{Y}_{2}=-30,869-0,3 * \mathrm{X}_{1-}$

$0,33 * X_{2}+0,35 * X_{3}+11,84 * X_{4}+6,81 * X_{5}$

\section{RESULTS AND DISCUSSION}

The main purpose of mathematical modelling is to predict and predict the expected properties of products. We knitted towels of different compositions, took samples from them and took the measured parameters as an unwanted parameter[10-15]. Using the obtained unwanted parameters, we predicted the water absorption rate and water absorption time of our products [16-26].

Table 2. Analysis of the values of high surface wetting time and high surface moisture absorption properties determination models.

\begin{tabular}{|c|c|c|c|c|}
\hline \multirow{2}{*}{$\begin{array}{c}\frac{0}{n} \\
\stackrel{2}{n}\end{array}$} & \multicolumn{2}{|c|}{ High surface wetting time, (s) } & \multicolumn{2}{c|}{$\begin{array}{r}\text { High surface moisture absorption } \\
\text { treatment, (\% S). }\end{array}$} \\
\cline { 2 - 5 } & Practical & Model value & Practical & Model value \\
\hline 1 & 6,46 & 6,86 & 49,80 & 43,43 \\
\hline 2 & 6,78 & 16,08 & 48,58 & 53,35 \\
\hline 3 & 5,68 & 1,30 & 48,65 & 47,11 \\
\hline 4 & 16,29 & 19,19 & 24,12 & 25,06 \\
\hline 5 & 17,26 & 19,32 & 23,98 & 24,98 \\
\hline 6 & 16,89 & 16,89 & 24,15 & 25,14 \\
\hline 7 & 1,31 & 5,42 & 19,93 & 20,57 \\
\hline 8 & 2,35 & 3,97 & 19,26 & 23,30 \\
\hline 9 & 1,98 & 10,10 & 20,21 & 27,02 \\
\hline 10 & 23,21 & 14,78 & 31,95 & 30,79 \\
\hline 11 & 22,90 & 18,63 & 30,25 & 25,90 \\
\hline 12 & 22,96 & 42,87 & 32,52 & 33,25 \\
\hline 13 & 5,34 & 4,10 & 24,83 & \\
\hline
\end{tabular}




\begin{tabular}{|l|l|l|l|l|}
\cline { 4 - 5 } 14 & 6,15 & 3,69 & 24,56 & 30,88 \\
\hline 15 & 5,89 & 34,38 & 25,01 & 16,25 \\
\hline 16 & 71,51 & 63,45 & 7,55 & 13,23 \\
\hline 17 & 70,27 & 58,62 & 7,85 & 9,80 \\
\hline 18 & 70,59 & 59,72 & 7,26 & 9,62 \\
\hline
\end{tabular}

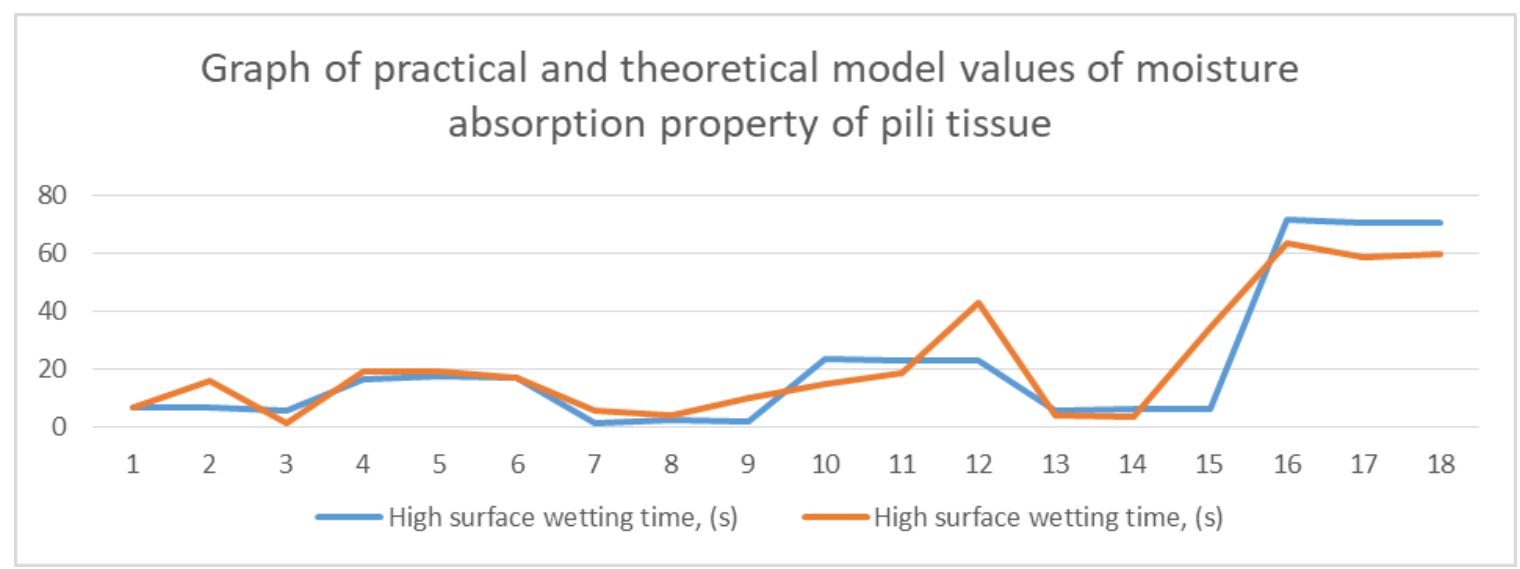

1-graph. Practical and model values for the time of absorption of pili tissue.

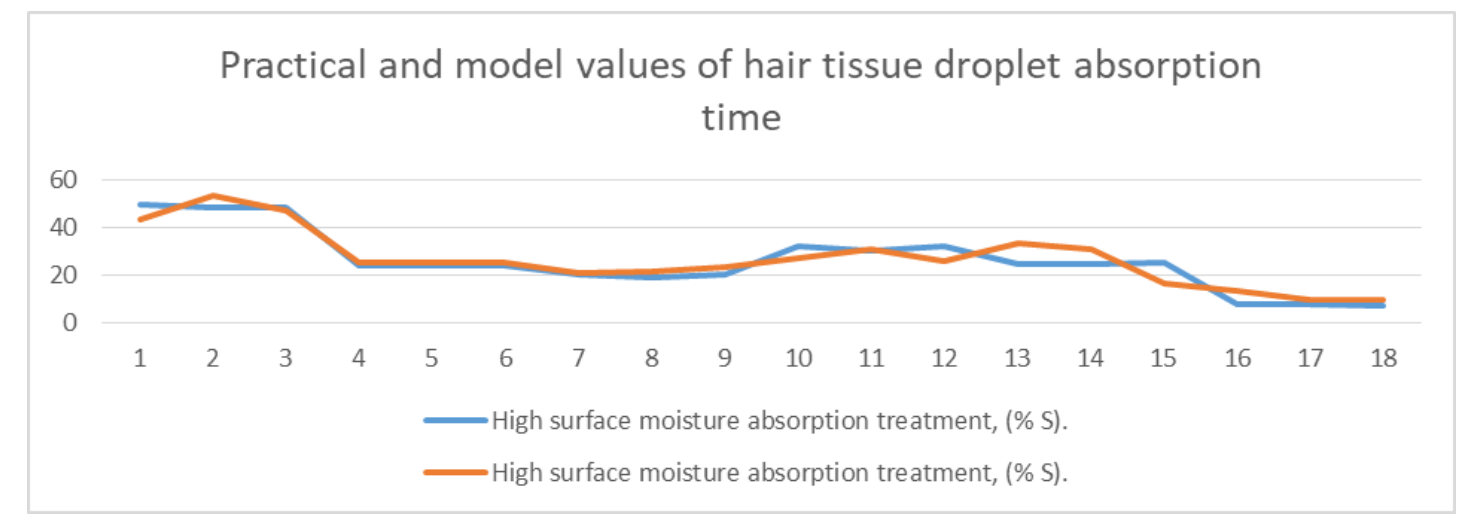

2-graph. Graph of practical and theoretical model values of moisture absorption of pili tissue.

\section{CONCLUSION}

The values of the mathematical model are compared with the practically obtained values in the graphs above. The graphs show that the values of these properties calculated from the model and the values measured from the finished product samples are very close to each other.

\section{REFERENCES}

1. Yilmaz, N. D., Powell, N. B., \& Durur, G. (2005). The technology of terry towel production. Technology and management.Vol 4. Issue 4. p.8.

2. Durur, G., \& Öner, E. (2013). The comfort properties of the terry towels made of cotton and polypropylene yarns. Journal 
of Engineered Fibers and Fabrics, 8(2), 155892501300800201.

3. Kosimov, A. A., Bakhriddinova, S. F. K., \& Abdulazizov, S. A. O. (2020). Classification Of Terry Products Made Of Natural Fiber. The American Journal of Engineering and Technology, 2(11), 133-141. https://doi.org/10.37547/tajet/Volume02ls sue11-21

4. Karahan, M. (2007). Experimental investigation of the effect of fabric construction on dynamic water absorbtion in terry fabrics. Fibres and Textiles in Eastern Europe, 15(3), 74.

5. Sevostyanov, A.G. (1980). Methods and tools for researching mechanical and technological processes in the textile industry.

6. Qosimov, A. A., Abdullayev, U. T., \& Abdulazizov, S. A. O. (2021). Mathematical modeling of physical properties of terry tissue products. ACADEMICIA: An International Multidisciplinary Research Journal, 11(3), 1963-1972. Doi: https://dx.doi.org/10.5958/2249-

7137.2021 .00973 .3

7. Bozgeyik, K. (1991). A quantitative investigation about towels (Doctoral dissertation, M. Sc. Thesis, Univ. of Ege, Inst. of Nat. and Appl. Sci., Dep. of Text. Eng., Izmir, 1991 (in Turkish)).

8. Okboyev A.R. (2020). Social Network Marketing and Its Development. International Journal of Research in Management \& Business Studies. Vol. 7 Issue 3. pp. 38-42.
9. Okboyev, A. R., \& Ashurkulov, O. J. (2020). Directions for the introduction of an integrated quality management system to increase the competitiveness of light industry enterprises. South Asian Journal of Marketing \& Management Research, 10(11), 107-110.

10. Khamraeva, S. A., Yusupova, N. B., Atambaev, D. D. O., \& Hasanov, M. H. O. (2020). The Importance Of The Extension Tool In Reducing The Inequality Of Yarn. The American Journal of Engineering and Technology, 2(08), 39-44. https://doi.org/10.37547/tajet/Volumeo2ls sue08-05

11. Atambayev, D. D. (2020). Analysis Of Fibrous Wastes Generated During Spinning Of Cotton Fiber In The ReSpinning System. The American Journal of Engineering and Technology, 2(09), 86-90.

12. Atambayev, D. D., Hasanov M. H. (2020). Analysis of Fibrous Waste Generated in the Preparation Departments of Spinning Mills and Cotton Processing. Vol.7 Iss. 9.

13. Ahmadjanovich, K. S., Lolashbayevich, M. S., \& Tursunbayevich, Y. A. (2020). Study Of Fiber Movement Outside The Crater Of Pnevmomechanical Spinning Machine. Solid State Technology, 63(6), 3460-3466.

14. Atambaev, D. D., \& Olimjonov, D. K. (2020). Production of arkok (enlama) hair wool fabrics on modern flexible fabric knitting machine in textile. ACADEMICIA: An International Multidisciplinary Research Journal, 10(11), 2294-2299. https://doi.org/10.5958/2249-

7137.2020.01599.2 
15. Jamshid, Y., Akbarjon, U., \& Olimjon, S. (2020). Dynamics of Interaction of a Single Fiber with a Headset of a Sampling Drum. Engineering, 12(6), 347-355. doi: 10.4236/eng.2020.126027

16. Mirkhojaev, M. M., \& Ahmadjanov, S. B. (2020). The study of physical and mechanical properties of different fabrics for suit gauze. ACADEMICIA: An International Multidisciplinary Research Journal, 10(11), 1046-1052.

17. Mirkhojaev, M. M., Iskandarov, O. P. U., Uralov, L. S. U., \& Yuldasheva, M. F. Q. (2021). Marketing Research On The Development Of Men's Polo T-Shirts And The Study Of Consumer Requirements. The American Journal of Applied sciences, 3(04), 10-17.

18. Mirkarimovich, M. M. (2020). Ergashov Jamshid Fakhridin ogli. Analysis Of Tanda Yarn Fiber Quality Indicators In Cotton Yarn Hardened Fabric Production. The American Journal of Engineering And Technology, (2), 82.

19. Mirxojayev, M. M. (2020). Method Of Assessing The Bending Resistance Of Yarns In Suit Folding Fabrics. The American Journal of Engineering and Technology, 2(09), 98-101.

20. Mirkhojaev, M. M., \& Iskandarov, O. F. O. (2020). The Study Of The Fineness Of Textile Materials In Small Manufacturing Enterprises. The American Journal of Engineering and Technology, 2(11), 174-178.

21. Maksudov, N. B., Nigmatova, F. U., Juldashev, Zh. K., \& Abduvaliev, R. R. (2018). Analiz deformacionnyh svojstv vysokojelastichnyh trikotazhnyh poloten dlja proektirovanija sportivnoj odezhdy [Analysis of deformation properties of highly elastic knitted fabrics for designing sportswear]. Universum: tehnicheskie nauki, (9 (54)). (in Russian).

22. Yuldashev, J. Q., \& Bobojanov, H. T. (2020). Study Of The Influence Of The Parameters Of The Sampling Zone On The Condition Of The Capture Of Fibers By The Drum Teeth. The American Journal of Engineering and Technology, 2(08), 75-78.

23. Bobojonov, H. T., Yusupov, A. A., Yuldashev, J. Q., \& Sadikov, M. R. (2020). Influence of deformation properties of yarn on the quality of knitted fabric. Test Engineering and Management, 2950229513.

24. Ugli, Y. A. A., Tokhirovich, B. H., \& Abdujabborovich, Y. S. (2021). Research into the effect of stretching couples on the quality of thread in a ring spinning machine. ACADEMICIA: An International Multidisciplinary Research Journal, 11(3), 164-171.

25. Ugli, Y. A. A., Tokhirovich, B. H., \& Qambaraliyevich, Y. J. (2021). Analysis of changes in the physical and mechanical properties of twisted yarns as a result of finishing. ACADEMICIA: An International Multidisciplinary Research Journal, 11(3), 117-122.

26. Abdullaev, A. R., \& Zulxumor, I. N. Q. (2021). A Review On: Analysis of The Properties of Thermal Insulation Materials. The American Journal of Interdisciplinary Innovations and Research, 3(05), 27-38. 